\title{
Advanced practice nursing: a possibility for Primary Health Care?
}

\author{
Prática avançada em enfermagem: uma possibilidade para a Atenção Primária em Saúde? \\ Práctica avanzada en enfermería: ¿una posibilidad para la Atención Primaria de Salud?
}

Manoel Vieira de Miranda Neto', Talita Rewa',
Valéria Marli Leonello', Maria Amélia de Campos Oliveira'
'Universidade de São Paulo, School of Nursing, Postgraduate Program in Nursing. São Paulo, Brazil.
How to cite this article:
$\begin{array}{r}\text { Miranda Neto MV, Rewa T, Leonello VM, Oliveira MAC. Advanced practice nursing: a possibility for Primary Health Care?. } \\ \text { Rev Bras Enferm [Internet]. 2018;71(Supl 1):716-21. [Issue Edition: Contributions and challenges of practices } \\ \text { in collective health nursing] DOI: http://dx.doi.org/10.1590/0034-7167-2017-0672 }\end{array}$

Submission: 09-27-2017 Approval: 12-13-2017

\begin{abstract}
Objective: Reflect on the role of advanced practice nursing (APN) in the context of Brazilian primary health care. Method: analysis of the main scientific productions and of the discussion on the implementation of APN. Results: there are favorable areas for the work of APN in primary health care, especially in the family health strategy. Professional master's degree and nurse residency programs constitute powerful training spaces. As a challenge, standardized definition of the roles of advanced practice nurses and of minimum training for work are necessary. Final considerations: researches that contribute to understanding the perspectives, facilitators, and barriers for APN are necessary, as well as determining the population's health needs and expectations concerning the role of these professionals.

Descriptors: Primary Health Care; Advanced Practice Nursing; Nursing Specialties; Human Resources in Health; Public Health Nursing.
\end{abstract}

\section{RESUMO}

Objetivo: Refletir sobre o papel da enfermagem com práticas avançadas (EPA) no contexto da atenção primária de saúde brasileira. Método: análise das principais produções científicas e da discussão sobre a implantação da EPA. Resultados: há campos de atuação favoráveis para EPA na atenção primária à saúde, em especial na estratégia saúde da família. A existência de mestrado profissional e programas de residência em enfermagem se configuram como potentes espaços de formação. Como desafio é necessária a definição padronizada dos papeis do enfermeiro com práticas avançadas e de formação mínima para atuação. Considerações finais: são necessárias pesquisas que colaborem para a compreensão de perspectivas, facilitadores e barreiras da EPA, assim como a identificação de necessidades de saúde da população e das expectativas do papel desses profissionais.

Descritores: Atenção Primária à Saúde; Prática Avançada de Enfermagem; Especialidades de Enfermagem; Recursos Humanos em Saúde; Enfermagem em Saúde Pública.

\section{RESUMEN}

Objetivo: Reflejar sobre el papel de la enfermería con prácticas avanzadas (EPA) en el contexto de la atención primaria de salud brasileña. Método: Análisis de las principales producciones científicas y de la discusión sobre la implantación de la EPA. Resultados: Hay campos de actuación favorables para la EPA en la atención primaria de salud, en especial en la estrategia salud de la familia. La existencia de maestría profesional y programas de residencia en enfermería se configuran como potentes espacios de formación. Como reto es necesaria la definición estandarizada de los papeles de la enfermería con prácticas avanzadas y de formación mínima para actuación. Consideraciones finales: Son necesarias las investigaciones que colaboran para la comprensión de perspectivas, facilitadores y barreras de la EPA, así como la identificación de necesidades de salud de la población y de las expectativas del papel de esos profesionales.

Descriptores: Atención Primaria de Salud; Práctica Avanzada de Enfermería; Especialidades de Enfermería; Recursos Humanos en Salud; Enfermería en Salud Pública. 


\section{INTRODUCTION}

It is observed worldwide growing interest in adopting practices that can innovate and reform health systems to respond to the problems arising from the health needs of populations, especially considering the increase in chronic conditions. Part of these problems is related to the health workforce, such as shortage of professionals and poor geographical distribution, more especially to training compatible with the provision of quality health care. Advanced practice nursing (APN) is currently considered to be one of these innovations.

APN has started in Canada and the United States of America more than 40 years ago and had an important development in the United Kingdom. More recently it was implemented in Ireland, Germany, Australia, New Zealand, China, Nigeria, among others ${ }^{(1-2)}$. In most countries, the implementation was carried out through important changes in legislation and professional regulation, transforming professional practice settings and nursing training spaces ${ }^{(3)}$.

More present in developed countries with higher income, APN is associated with increased and improved coverage and users' access to health services. The need for and the interest in the introduction of APN in middle and low-income countries are already well documented. More than 70 nations are interested in discussing how to include APN in their health practice settings. Its implementation is seen as an important strategy for strengthening the health workforce, particularly with regard to capacity building, recruitment, and maintenance of nurses in health services ${ }^{(3-4)}$.

APN contributes to improving the quality of care, to increasing coverage in health, and to reducing healthcare costs. Studies indicate that the results of the performance of advanced practice nurses are as good or better when compared with the same care performed by physicians. There is also evidence of high rates of user satisfaction regarding the care provided by such nurses ${ }^{(3-5)}$.

APN can be considered an instrument of innovation, because it contributes to improving the health care of populations of greater vulnerability, such as indigenous peoples, persons living in violent communities or of difficult access, rural communities, riverine populations, immigrants, the elderly, children, people with disabilities, people with mental disorders, among others. It also contributes to the capacity building of care practices for illness prevention, health promotion and rehabilitation in various points of the health care network ${ }^{(3)}$.

However, its successful implementation requires extensive and thorough assessment of the needs of the health care services, of the health care network, and of the health care needs of the country's population. It also requires the involvement of all parties that collaborate and share the nursing practice setting, especially physicians, but also of other professional categories and of the users, in order to align expectations about the professional skills and scope of the APN practice ${ }^{(3)}$.

Seeking to understand the process of development, implementation, and assessment of APN, some authors ${ }^{(6)}$ determined six barriers that hinder its introduction: (1) confusion in terminology; (2) failure in the definition of roles and objectives; (3) emphasis on substitution and support of physicians; (4) underutilization of all areas of APN; (5) failure in the analysis of the macrostructural facts (society, health care system, nursing workforce, associations, agencies for professional regulation and standardization, training institutions, workplaces); and (6) limited use of evidence-based approaches. Therefore, it is recommended that these aspects are primarily analyzed so the introduction of EPA achieves greater success.

There are other authors ${ }^{(7)}$ who consider that APN increases the scope of nurse practice and contributes to improve accessibility and coverage in health. To that end, they suggest to those countries that wish to implement it three political lessons:

1. Discussions should be conducted considering that there is substantial evidence concerning the equivalence of quality, safety and patient satisfaction for the care provided by advanced practice nurses in relation to physicians, seeking to plan effectively how to implement new roles of practice.

2. Policies for regulation, standardization, remuneration, funding, and adequate training for advanced practice nurses should be ensured.

3. It should be considered that APN improves nursing as a career and that, therefore, it is important to develop policies that strengthen the professional category.

\section{THE ADVANCED PRACTICE NURSE}

APN integrates research, education, health care practice, and management. Thus, the professional that performs it should have a high degree of professional autonomy and competence to make clinical decisions, perform evaluations, diagnosis, and prescriptions, being responsible for case management, evaluation and implementation of programs and plans for care and reference for the first point of contact of users with health services ${ }^{(8)}$.

Several designations are used to refer to professionals trained to conduct advanced practice nursing, such as family nurse practitioner, adult nurse practitioner, primary care nurse practitioner, nurse midwife, clinical nurse specialist, nurse anaesthetist, community health nurse practitioner, women's health nurse practitioner, among others ${ }^{(8)}$.

The most common designations are the nurse practitioner (NP) and clinical nurse specialist, with the first having greater involvement with the practice and clinical care and the second having more responsibilities related to nonclinical activities, such as education, health services management, and involvement in initiatives to improve the quality of care, such as the development of clinical protocols and guidelines ${ }^{(1-3)}$.

In general, nurse practitioners were introduced in contexts in which the health needs were related to more vulnerable populations and in locations with scarce health resources, such as rural areas and remote areas of difficult access. While the introduction of clinical nurse specialist is associated with contexts with need of specialist care and leadership for improvement in the quality of care through advanced practices based on scientific evidence ${ }^{(3)}$.

Seeking to contribute to the understanding of advanced practice nursing, the International Council of Nurses (ICN) has developed the following definition for advanced practice nurses (nurse practitioners): 
A Nurse Practitioner/Advanced Practice Nurse is a registered nurse who has acquired the expert knowledge base, complex decision-making skills and clinical competencies for expanded practice, the characteristics of which are shaped by the context and/or country in which s/he is credentialed to practice. A Master degree is recommended for entry level.

Among the APN practices, the ICN included seven clinical activities $^{(8)}$ :

1. Autonomy to prescribe: valid for any medication that requires a prescription by an authorized supplier, regardless of medical control. The prescription of medications or devices of free sale are not considered advanced clinical activities.

2. Autonomy to request medical tests and devices: includes the request for laboratory tests, diagnostic images or devices requiring official requests. The requests for specific tests related to nursing are not considered advanced clinical activities.

3. Autonomy to perform diagnosis or advanced health assessment: capacity to perform differential diagnosis, of side effects, staging of disease, or advanced health assessments. Specific nursing diagnoses are not considered advanced clinical activities.

4. Autonomy to indicate medical treatments: make decisions about medical treatments and therapies. The therapies recognized as nursing activities such as treatment of wounds are not considered advanced clinical activities.

5. Responsibility for a set of users (caseload): being the reference professional for a set of specific users.

6. Autonomy to refer and refer back users: possibility of referring users to other health services or health professionals at the different levels of the health care network.

7. First point of contact: being the reference professional for the first point of contact for users with undifferentiated diseases and/or established chronic conditions.

The ICN considers that advanced practice nurses must have advanced level training, achieved through recognized graduate programs for this function, preferably at master's level, they must also obtain license, certification, and registration from competent supervisory agencies of the professional practice ${ }^{(8)}$.

The Canadian Nurses Association (CNA) recommends that advanced practice nurses develop optimized clinical practices because of their graduate training, using in-depth knowledge able to meet the health needs of individuals, families, collectivities, and populations. They must be able to analyze and synthesize knowledge, understand, interpret, and apply the theory and research in nursing, contributing to develop the profession and the evidence-based practices ${ }^{(1)}$.

Advanced practice nurses must develop skills in a specific area of expertise and be able to provide effective and efficient health care with a high degree of autonomy. Moreover, they must be recognized for their leadership by the health care team and by the users; use scientific evidence to guide their clinical practice, integrating their knowledge in nursing with clinical experience and other related areas; explain and apply theoretical frameworks in their professional practice; understand, conduct, and disseminate evidence-based nursing. They must also show capacity to propose, plan, implement, participate in, and assess health programs according to the health needs of users and services; know, perform, and implement translational research; make decisions based on advanced judgment, and make critical analysis of health systems and policies ${ }^{(1)}$.

APN regulation mechanisms must ensure that the professional has the right to diagnose and the authority to prescribe medications and treatments; and to give users referral to other points of care in the health care network, in addition to admitting users to health services. To this end, it is essential that they have the title of advanced practice nurse recognized legally in the context in which they work ${ }^{(8)}$.

A Canadian study found high levels of job satisfaction of nurse practitioners, especially in relation to professional autonomy, collaborative and collegiate practice, and for feeling constantly challenged in their professional practice. The dissatisfaction rates were related to aspects of remuneration for the work $^{(9)}$.

Advanced practice nurses assume roles traditionally performed by physicians; therefore, this category's involvement is essential for success in its implementation. To this end, the advances that APN can bring should be highlighted, instead of the discourse of substitution for the medical professional ${ }^{(3)}$.

At the international level it is recommended that national associations seek to develop a network of collaboration between countries, sharing resources and seeking consensus on definitions and terminology regarding the role of APN. At the national level they should foster initiatives for the development of consensus and evidence for the implementation and assessment of the role of APN. It is also essential to build a network of people and institutions interested in the development of the profession, in addition to promoting reflections on the political conditions, the barriers and the potential of the context so as to achieve transformations in the health system ${ }^{(3)}$.

\section{ADVANCED PRACTICE NURSING IN PRIMARY HEALTH CARE}

Research on the development of the Canadian APN in the last 40 years found facilitators and barriers to the advancement of this practice, especially in Primary Health Care (PHC). The authors reinforced the role of the advanced practice nurse for the improvement of the quality of care and made important recommendations on the need for political reforms for regulation, training, remuneration, financing, and activity of these professionals at national level ${ }^{(10)}$.

Another study ${ }^{(11)}$ presented the current situation on the workforce in the American PHC, indicating the need to strengthen the activity of APN in this health care context, in particular due to the increasing demand for health services and insufficient number of physicians, with expected shortage of these professionals for 2020. Advanced practice nurses were considered effective and efficient alternative for $\mathrm{PHC}$ in the American health system. 
A systematic review ${ }^{(12)}$ of controlled clinical trials found little difference regarding the safety and effectiveness of PHC practices carried out by physicians and advanced practice nurses. In some cases the performance of nurses was, even, considered to be of superior quality, especially with regard to physiological measurements, user satisfaction, and costs, confirming that advanced practice nurses are fully able to provide safe and effective care.

In relation to satisfaction concerning the care provided by advanced practice nurses in PHC, a Swedish research found that users reported high levels of satisfaction as to the care provided by these professionals, particularly in relation to the access and length of care. Those who were informed about the role of the professional before being provided service were even more satisfied ${ }^{(13)}$.

A comparative study ${ }^{(14)}$ conducted in 39 countries, through consultation with specialists and literature review, analyzed the stages of development of APN in PHC in different international settings. In eleven countries advanced practice nurses assumed advanced clinical activities ${ }^{(8)}$, with changes in practices that were formerly performed by physicians. In other sixteen countries there were still limitations in practices, and in 12 countries there were no changes. Considering the results, the study ${ }^{(14)}$ emphasized the importance of political and educational reforms to maximize the scope of clinical practice of nurse practitioners and so changes occur. This will require clear and standardized definition of the roles and of the minimum training for the function.

In addition, the leadership and protagonism of national associations of nurses and agencies for standardization, regulation, and professional supervision are also essential, and national and international intersectoral coordination are highly recommended.

\section{ADVANCED PRACTICE NURSING IN LATIN AMERICA AND IN THE CARIBBEAN}

Although international experiences enable establishing different stages of development of APN in several countries, discussions and researches on the subject in Latin America and in the Caribbean are still scarce. In this region, the health needs are extremely complex and the health systems show important disparities, being challenged by the high demand of communicable and non-communicable diseases, difficulties in allocating resources and manpower in health, limited coverage of services and quality health care ${ }^{(15)}$.

In 2014, the Executive Committee of the Pan American Health Organization (PAHO) presented a strategic plan to achieve universal health coverage understood as the right to "equal access to comprehensive and quality health services according to the needs throughout life" (PAHO, 2014. p. 1). To this end, the health systems must be efficient; a major challenge to the achievement of universal health coverage is the composition and the training of the health workforce, especially to work in $\mathrm{PHC}^{(16)}$.

The plan features four strategic lines to be adopted to ensure universal coverage and access to health services: (1) increase the access to comprehensive and quality health services focused on individuals and communities, respecting the principle of equity; (2) strengthen the management and governance of the health systems; (3) increase and improve health financing, with equity and efficiency, seeking to eliminate the direct payment by users; and (4) strengthen intersectoral coordination to address the social determinants of health. APN was considered to be an important tool to support the development of these lines ${ }^{(16)}$.

In 2013, the PAHO presented the resolution "Human resources in health: improve access to qualified health professionals in health systems based on primary health care." Considering the strategic and critical role of the health workforce to achieve universal coverage and access seeking to development the health systems, it recommended educational reforms for the training of health professionals to work in systems based on PHC. It also recommended the increase in positions for relevant professionals to the work in PHC, such as family physicians, advanced practice nurses, and non-medical clinical professionals in the region of Latin America.

In 2014, it was released the first Brazilian publication ${ }^{(17)}$ reflecting on the role of APN in Latin America, in the form of editorial of Revista Brasileira de Enfermagem. The authors reflected on how APN can contribute to the advancement of universal coverage and access to health services, reinforcing the importance of changes in the nursing workforce training. According to them, these changes should occur through the development of policies that strengthen the training at the undergraduate and graduate levels, the regulation, funding, permanent education, professional practice, and remuneration. They also considered important the strengthening of nursing as a professional category, assuming a leading role in the processes of transformation of the health systems.

Given the success of APN as a strategy for capacity building of human resources in health in many countries, it is believed that its implementation in Latin America and in the Caribbean can contribute to improve the universal coverage and access to health services ${ }^{(18)}$. Its successful introduction can also serve to guide the implementation in other medium or low income countries $^{(18)}$.

In relation to the countries of Latin America and of the Caribbean, Brazil has a leading position due to providing more conditions to establish graduate programs in APN, as it already has 51 academic master's programs, 15 professional master's programs, and $36 \mathrm{PhD}$ programs in Nursing ${ }^{(18)}$.

Several authors highlight the potential of professional master's programs for training in APN, considering their educational role related to technological innovation, knowledge translation, and capacity building for practice in advanced activities. This type of training may be suitable for the training of advanced practice nurses to work in $\mathrm{PHC}$ in the Brazilian context ${ }^{(19-20)}$.

In 2015, discussions began in Brazil to implement APN in PHC. Representatives of the Federal Council of Nursing and of the Brazilian Association of Nurses meeting at the PAHO headquarters discussed prospects for APN in the Brazilian context. In recent years there have been several meetings and conferences on the subject in the country and the PAHO has developed initiatives to support Brazil in this process ${ }^{(21)}$. 
In 2016, nursing leaders from Latin America, including Brazil, met with American and Canadian researchers to participate in the "Advanced practice nursing summit: developing advanced practice nursing competencies in Latin America to contribute to universal health," held at McMaster University in Canada, to discuss the increase in the scope of nurse practice in PHC and the role of APN in the different contexts.

They observed, as strengths of Brazil, the existence of favorable areas for the activity of advanced practice nurses in $\mathrm{PHC}$, even with a lower degree of professional competition, if the practice settings of the family health strategy and the existence of residency programs in nursing are considered. The challenges observed concerned the Ministry of Health lacking understanding about the role of APN and the fact that the graduate programs provide predominantly theoretical education, and are not considered clinical training programs.

A study ${ }^{(22)}$ with 173 nursing leaders in Latin America and in the Caribbean found that they were all familiar with the role of APN; however, most were unaware of the legislation and regulation for this kind of activity. It is highlighted, therefore, the importance of teacher capacity building for training in APN and the need for curriculum reforms with emphasis on PHC.

Another author ${ }^{(23)}$ considers that Brazil provides favorable conditions for the development of the role of APN, as it has the foundations for regulation of the practice, especially Law No. 7498/1986, which regulates the professional practice of the Nurse, and Ordinance No. 2,488, of October 21, 2011, which approves the National Basic Care Policy (PNAB). The Law of Professional Practice describes as private activity of nurses carrying out nursing consultation that includes care of greater complexity and requires prompt decision making through scientific knowledge, allowing the prescription of medications approved in public health programs. The PNAB expresses that the professionals should follow the recommendations of their regional councils. Both feature favorable elements to the development of $\mathrm{APN}^{(23)}$.

Although the country shows favorable conditions for the development of APN, researches that contribute to understand perspectives, facilitators, and barriers concerning the practice in the national setting are necessary, as well as to determine the population's health needs and expectations as to the role of these professionals.

\section{REFERENCES}

1. Canadian Nurses Association, CNA. Factsheet: role of the nurse practitioner around the world. CNA [Internet]. 2002 [cited 2017 May 30]. Available from: https://www.cna-aiic.ca/ /media/cna/page-content/pdf-fr/fs11_role_nurse_practitioner_march_2002_e. pdf?la $=$ en

2. International Council of Nurses, ICN, CIE. Nurse Practitioner/Advanced Practice Nursing Network Country Profiles. ICN [Internet]. 2014 [cited 2017 May 30]. Available from: http://international.aanp.org/content/docs/countryprofiles2014.pdf

3. Bryant-Lukosius D, Martin-Misener R. ICN Policy Brief. Advanced Practice Nursing: an essential component of country level human resources for health. ICN [Internet]. 2016 [cited 2017 Jun 03]. Available from: http://www.icn.ch/images/stories/documents/ pillars/sew/HRH/ICN_Policy_Brief_6.pdf

4. Organização das Nações Unidas. ONU. Assembleia Geral das Nações Unidas. Transforming our world: the 2030 agenda for sustainable development. DRAFT for consultation[Internet]. ONU. 2015[cited 2017 Jun 03]. Available from: http://www.who.int/ hrh/resources/glob-strat-hrh_workforce2030.pdf?ua = 1

5. Kurtzman ET, Barnow BS. A comparison of nurse practitioners, physician assistants, and primary care physicians' patterns of practice and quality of care in health centers. Med Care [Internet]. 2017 [cited 2017 Jul 03];55(6):615-22. Available from: https:// insights.ovid.com/pubmed?pmid $=28234756$

6. Bryant-Lukosius D, DiCenso A, Browne G, Pinelli J. Advanced practice nursing roles: development, implementation and evaluation. J Adv Nurs [Internet]. 2004 [cited 2017 Jun 10];48(5):519-29. Available from: http://onlinelibrary.wiley.com/ doi/10.1111/j.1365-2648.2004.03234.x/epdf

7. Maier C, Aiken L. Expanding clinical roles for nurses to realign the global health workforce with population needs: a commentary. Isr J Health Policy Res [Internet]. 2016 [cited 2017 May 30];5(1):21. Available from: https://www.ncbi.nlm.nih.gov/pmc/articles/ PMC4897947/pdf/13584_2016_Article_79.pdf

8. International Council of Nurses, ICN, CIE. Nurse practitioner/advanced practice nurse: definition and characteristics. ICN [Internet]. 2009[cited 2017 Jun 03]. Available from: https://acnp.org.au/sites/default/files/33/definition_of_apn-np.pdf

9. Lamarche K, Tullai-McGuinness S. Canadian nurse practitioner job satisfaction. Nurs Leadersh [Internet]. 2009 [cited 2017 May 20];22(2):41-57. Available from: http://www.longwoods.com/content/20797

10. DiCenso A. Advanced practice nursing in Canada: overview of a decision support synthesis. Nurs Leadersh[Internet]. 2010 [cited 2017 May 30];23(Spce):15-34. Available from: http://www.longwoods.com/content/22267

11. Bodenheimer T, Bauer L. Rethinking the Primary Care Workforce: an expanded role for nurses. N Engl J Med [Internet]. 2016 [cited 2017 Jun 03];375(11):1015-7. Available from: http://www.nejm.org/doi/pdf/10.1056/NEJMp1606869

12. Swan M, Ferguson S, Chang A, Larson E, Smaldone A. Quality of primary care by advanced practice nurses: a systematic review. Int J Qual Health Care [Internet]. 2015 [cited 2017 May 30];27(5):396-404. Available from: https://academic.oup.com/intqhc/ 
article-lookup/doi/10.1093/intqhc/mzv054

13. Bergman K, Perched U, Eriksson I, Lindblad U, Fagerstrom L. Patients' satisfaction with the care offered by advanced practice nurses: a new role in Swedish primary care. Int J Nurs Pract [Internet]. 2013 [cited 2017 Jun 03];19:326-33. Available from: http:// onlinelibrary.wiley.com/doi/10.1111/ijn.12072/epdf

14. Maier C, Aiken L. Task shifting from physicians to nurses in primary care in 39 countries: a cross-country comparative study. Eur J Public Health [Internet]. 2016b [cited 2017 Jun 03];26(6):927-34. Available from: https:/academic.oup.com/eurpub/ article-lookup/doi/10.1093/eurpub/ckw098

15. Musgrove P. Challenges and solutions in health in Latin America [Internet]. 2007 [cited 2017 Jun 03]. Available from: http:// idbdocs.iadb.org/wsdocs/getdocument.aspx?docnum $=1186232$

16. Organização Pan-Americana de Saúde, OPAS. Estratégia para cobertura universal de saúde. CE 154/12. In: 154a Sessão do Comitê Executivo [Internet]. 2014, Jun 16-20; Washington. EUA [cited 2017 Jun 17]. Available from: http://www.paho.org/bra/ images/stories/Documentos2/ce154\%20tema\%204\%203\%20verso \%207\% 20ago.pdf?ua = 1

17. Cassiani S, Zug K. Promoting the Advanced Nursing Practice role in Latin America. Rev Bras Enferm [Internet]. 2014 [cited 2017 Jun 18];67(5):673-4. Available from: http://www.scielo.br/pdf/reben/v67n5/0034-7167-reben-67-05-0677.pdf

18. Bryant-Lukosius D, Valaitis R, Martin-Misener R, Donald F, Peña L, Brousseau L. Advanced practice nursing: a strategy for achieving universal health coverage and universal access to health. Rev Latino-Am Enfermagem [Internet]. 2017 [cited 2017 Jun 18];25:e2826. Available from: https://www.ncbi.nlm.nih.gov/pmc/articles/PMC5288863/pdf/0104-1169-rlae-25-02826.pdf

19. Scochi CGS, Gelbcke FL, Ferreira MA, Alvarez AM. Professional Master's Degree: potential contribution to Advanced Practice Nursing. Rev Bras Enferm [Internet]. 2015 [cited 2017 Jun 18];68(6):874-7. Available from: http://www.scielo.br/pdf/reben/v68n6/ en 0034-7167-reben-68-06-1186.pdf

20. Zanetti M. Advanced nursing practice: strategies for training and knowledge building. Rev Latino-Am Enfermagem [Internet]. 2015 [cited 2017 Jun 18];23(5):779-80. Available from: http://www.scielo.br/pdf/rlae/v23n5/0104-1169-rlae-23-05-00779.pdf

21. Cassiani S, Rosales L. Initiatives towards Advanced Practice Nursing Implementation in the Region of the Americas. Esc Anna Nery Rev Enferm[Internet]. 2016 [cited 2017 Apr 21];20(4):e20160081. Available from: http://www.scielo.br/pdf/ean/v20n4/en_14148145-ean-20-04-20160081.pdf

22. Zug K, Cassiani S, Pulcini J, Garcia A, Aguirre-Boza F, Park J. Advanced practice nursing in Latin America and the Caribbean: regulation, education and practice. Rev Latino-Am Enfermagem [Internet]. 2016 [cited 2017 May 30];24:e2807. Available from: http://www.scielo.br/pdf/rlae/v24/0104-1169-rlae-24-02807.pdf

23. Toso B. Práticas Avançadas de Enfermagem na Atenção Primária à Saúde: estratégias para implantação no Brasil. Enferm Foco [Internet]. 2016 [cited 2017 May 30];7(3/4):36-40. Available from: http://revista.portalcofen.gov.br/index.php/enfermagem/article/ viewFile/913/343 